\title{
Correction to: Association between plasma interleukin-33 level and acute exacerbation of chronic obstructive pulmonary disease
}

Hyonsoo Joo', Seoung Ju Park², Kyung Hoon Min ${ }^{3^{*+}}$ and Chin Kook Rhee ${ }^{4^{*+}}$

\section{Correction to: BMC Pulm Med (2021) 21:86}

https://doi.org/10.1186/s12890-021-01423-8

Following publication of the article [1], it came to the authors' attention that incorrect $\mathrm{R}$ values had been provided for Fig. 4a, b.
The figure has been updated in the published article and the correct values may be found in this correction article.

The authors thank you for reading and apologize for any inconvenience caused.

*Correspondence: minkyunghoon@korea.ac.kr; chinkook77@gmail.com ${ }^{\dagger}$ Kyung Hoon Min and Chin Kook Rhee contributed equally to this work.

${ }^{3}$ Division of Pulmonary, Allergy, and Critical Care Medicine, Department of Internal Medicine, Korea University Guro Hospital, Korea University College of Medicine, 148, Gurodong-ro, Guro-gu, Seoul 08308, Republic of Korea

${ }^{4}$ Division of Pulmonary, Allergy and Critical Care Medicine, Department of Internal Medicine, Seoul St. Mary's Hospital, College of Medicine, The Catholic University of Korea, 222 Banpodaero, Seochogu, Seoul 06591, Republic of Korea

Full list of author information is available at the end of the article regulation or exceeds the permitted use, you will need to obtain permission directly from the copyright holder. To view a copy of this licence, visit http://creativecommons.org/licenses/by/4.0/. The Creative Commons Public Domain Dedication waiver (http://creativecommons.org/publicdomain/zero/1.0/) applies to the data made available in this article, unless otherwise stated in a credit line to the data. 
a

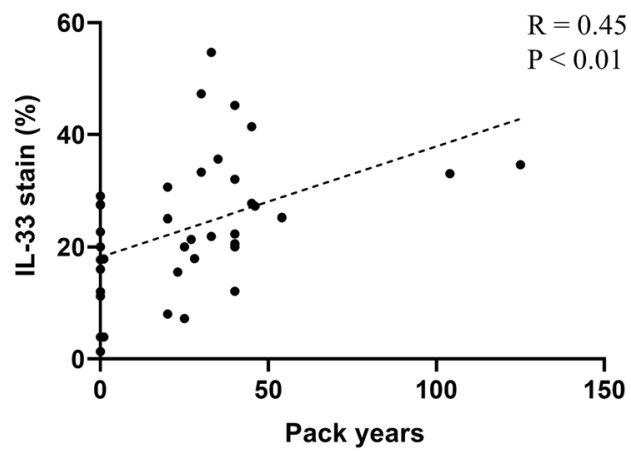

b

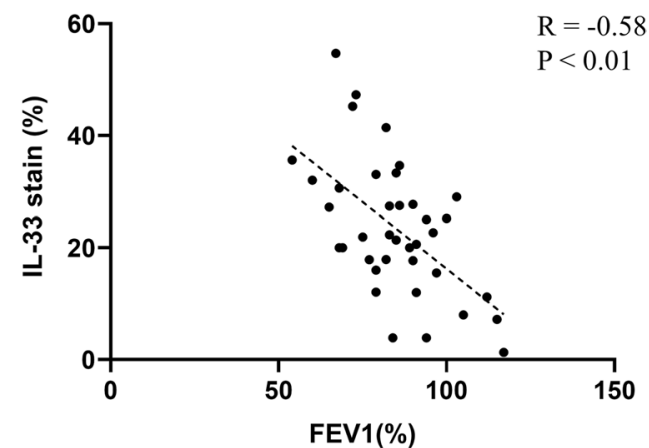

Fig. 4 Correlation between the expression of IL-33 in lung tissue and amount of smoking (a). Correlation between IL-33 and FEV $(\%)$ (b). Abbreviations: R, Pearson correlation coefficient; IL, interleukin; FEV 1 , forced expiratory volume in $1 \mathrm{~s}$

\section{Author details}

'Division of Pulmonary, Allergy and Critical Care Medicine, Department of Internal Medicine, Uijeongbu St. Mary's Hospital, College of Medicine, The Catholic University of Korea, Seoul, Republic of Korea. ${ }^{2}$ Division of Pulmonary, Allergy and Critical Care Medicine, Department of Internal Medicine, Jeonbuk National University Hospital, Jeonbuk National University Medical School, Jeonju, Republic of Korea. ${ }^{3}$ Division of Pulmonary, Allergy, and Critical Care Medicine, Department of Internal Medicine, Korea University Guro Hospital, Korea University College of Medicine, 148, Gurodong-ro, Guro-gu Seoul 08308 , Republic of Korea. ${ }^{4}$ Division of Pulmonary, Allergy and Critical Care Medicine, Department of Internal Medicine, Seoul St. Mary's Hospital, College of Medicine, The Catholic University of Korea, 222 Banpodaero, Seochogu, Seoul 06591, Republic of Korea.

Published online: 29 October 2021

\section{Reference}

1. Joo H, Park SJ, Min KH, et al. Association between plasma interleukin-33 level and acute exacerbation of chronic obstructive pulmonary disease. BMC Pulm Med. 2021;21:86. https://doi.org/10.1186/s12890-021-01423-8.

\section{Publisher's Note}

Springer Nature remains neutral with regard to jurisdictional claims in published maps and institutional affiliations. 